\title{
NEW INSIGHTS ON THE SYSTEMATIC CLASSIFICATION OF CERTAIN PALYNOLOGICAL TAXA (TINTINNOMORPHS) FROM HOLOCENE DEPOSITS OF THE COASTAL PLAIN OF SOUTHERN BRAZIL
}

\author{
WAGNER GUIMARÃES DA SILVA \\ Instituto Federal de Educação, Ciência e Tecnologia do Rio Grande do Sul, IFRS, Campus Osório. Rua Santos Dumont, \\ 2127, 95.520-000, Osório, RS, Brazil.wagner.guimaraes.silva@gmail.com
}

PAULO ALVES DE SOUZA

Laboratório de Palinologia Marleni Marques Toigo, Departamento de Paleontologia e Estratigrafia, Instituto de Geociências, Universidade Federal do Rio Grande do Sul. Av. Bento Gonçalves, 9500, 91.540-000, Porto Alegre, RS, Brasil. paulo.alves.souza@ufrgs.br

ISABEL VAN WAVEREN

Naturalis Biodiversity Center, P. O. Box 9517, RA Leiden, The Netherlands. isabel.vanwaveren@naturalis.nl

\begin{abstract}
Tintinnomorphs is a term used for the grouping of palynomorphs resembling organic remains of tintinnids, which are not always identifiable as true lorica, cysts or pouch, being able to correspond to other protozoans and may even represent others structures of distinct organisms, such as rotifers and turbellarians. This paper presents tintinnomorphs recorded in Holocene sediments of the well PSC-03, drilled in the Coastal Plain of Santa Catarina, southern Brazil. A total of six tintinnomorphs types is described and illustrated (SPHERO-1, ELELNO-14, ESABNO-6, HEXANO-2, RECTNO-1, AROBNO-3), some of which are compared with specimens previously reported from Quaternary deposits of southern Brazil, southern South America and other regions of the world. Although tintinomorphs are associated to marine palynomorphs, they cannot be used as a conclusive paleoenvironmental evidence due to uncertainties about their biological affinity.
\end{abstract}

Key words: tintinnomorphs, tintinnids, Holocene, Coastal Plain of Santa Catarina.

RESUMO - Tintinomorfos é um termo usado no agrupamento de palinomorfos assemelhados a restos orgânicos de tintinídeos, os quais nem sempre são passíveis de serem identificados como verdadeiras lóricas, cistos ou bolsas, podendo corresponder a outros protozoários e até representar outras estruturas de organismos distintos, como rotíferos e turbelários. Este trabalho apresenta tintinomorfos registrados em sedimentos do Holoceno do poço PSC-03, perfurado na Planície Costeira de Santa Catarina, sul do Brasil. Um total de seis tipos de tintinomorfos é descrito e ilustrado (SPHERO-1, ELELNO-14, ESABNO-6, HEXANO-2, RECTNO-1, AROBNO-3), alguns dos quais comparados a espécimes previamente registrados em depósitos quaternários do sul do Brasil, sul da América do Sul e outras regiões do mundo. Embora estejam associados a palinomorfos marinhos, tintinomorfos não podem ser utilizados como indicadores paleoambientais conclusivos devido às incertezas sobre sua afinidade biológica.

Palavras-chaves: tintinomorfos, tintinídeos, Holoceno, Planície Costeira de Santa Catarina.

\section{INTRODUCTION}

Tintinnids are unicellular, planktonic, heterotrophic, protist organisms of reduced size $(20-200 \mu \mathrm{m})$, belonging to the phylum Ciliophora. The cell is always surrounded by a test named lorica, which is secreted by the organism, organic or agglutinated with biogenic and abiogenic particles attached to the wall (Barnes, 1990; Adamonis et al., 2007; Agatha \& Strüder-Kypke, 2013). The lorica presents distinct shapes at the intraspecific level, depending on the environmental conditions (e.g. temperature, salinity and particle availability) during its construction, thus influencing its size, shape and structure (Agatha \& Strüder-Kypke, 2013).
Due to the chemical composition (proteins and polysaccharides) and the agglutinating property of the lorica, tintinnomorpha are a unique suborder of the Ciliophora likely to remain as fossil record (Canudo, 2004; Adamonis et al., 2007; Lipps et al., 2013) as only two features make them assignable to the tintinnids: the shape and the composition (Lipps et al., 2013).

Different approaches to the chemical composition (chitin, pseudochitin, cellulose, proteins and polysaccharides) and to the texture (delicate, gelatinous, membranous and firm) of the constitution of organic lorica are verified in the literature (Tappan \& Loeblich, 1968; Van Waveren, 1994; Canudo, 2004; Lipps et al., 2013). Recent studies have shown that 
many of these unicellular organisms are able to construct several types of lorica, which can lead to classifications into divergent tintinnids families (Agatha \& Strüder-Kypke, 2013).

Nevertheless, many loricae and cysts are recovered by palynological processing (Reid \& John, 1978; Meckler et al., 2008; Mudie et al., 2010, 2011; Pienkowski et al., 2011, 2013), being classified within the palynomorphs as zoomorphs (Traverse, 1994). In modern marine sediments, a large quantity and variety of tintinnid cysts and loricae is known (Reid, 1975; Reid \& John, 1978; Van Waveren, 1994; Van Waveren \& Visscher, 1994; Kawamura, 2004; Hardy \& Wrenn, 2009; Lipps et al., 2013; Pienkowski et al., 2011, 2013; Matsuoka et al., 2017).

Fossil tintinnids are almost exclusively marine, comprising few described taxa. During the fossilization, diagenetic processes can change the morphological characters of the ciliates specimens, limiting an accurate description. As a result, there are misconceptions in the descriptions and taxonomic assignments of several specimens attributed to the group, and molecular analysis is not adequate for taxonomic assignment of fossil taxa (Lipps et al., 2013).

According to Canudo (2004), the ciliate fossil record is composed almost exclusively by loricae analogue to the tintinnids loricae, some of which belong to other groups. Due to the great difficulty in observing and interpreting the tintinnids fossils, Canudo (2004) defends the creation of a comprehensive term (e.g. tintinnoids or tintinnomorphs) to encompass the true tintinnid loricae and similar forms, thus minimizing the mistaken designations.

However, morphological studies on the organic remains attributed to tintinnids are needed. Van Waveren (1994) proposed an informal morphological system, with description and illustration of the cysts, loricae and the pouches in which the cysts were originally encapsulated, as well as considering their ontogenetic stages. As a result, 76 morphological types were presented, grouped under the term "tintinnomorphs". This term is used to link organic remains found in palynological preparations resembling tintinnids, which are not always identifiable as true lorica, cysts or pouches, being able to correspond to other protozoans and may even represent structures of other distinct organisms, such as rotifers and turbellarians.

Certain specimens resembling tintinomorphs were recorded from Quaternary deposits of the Brazilian Coastal Plain, especially from Rio Grande do Sul (CPRS) and Santa Catarina (CPSC), described as flatworm eggs (Neves \& Bauermann, 2003; Cancelli et al., 2012; Roth \& Lorcheistter, 2016). Many of them are comparable to some morphological types proposed by Van Waveren (1994).

The palynological analysis of a core sample taken from the Coastal Plain of Santa Catarina revealed the presence of tintinnomorphs at several levels. These were found associated with dinoflagellate cysts, foraminiferal linings, along with terrestrial nature taxa (spores, pollen grains, fungi and freshwater algae). The main goals of this paper are to describe, Brazilian Holocene tintinnomorphs using the Van Waveren (1994) descriptive system; compare them with specimens previously reported for the Quaternary of southern Brazil, southern South America, and similar forms from other regions of the world; and discuss their environmental significance.

\section{ECOLOGICAL AND STRATIGRAPHIC CONSIDERATION OF TINTINNIDS}

\section{Ecology}

Tintinnids are one of the most important and abundant components of microzooplankton (Tappan \& Loeblich, 1968; Tenenbaum \& Gomes, 2006). Currently 1,200 species are known, allocated in 75 genera, most of them distributed in marine and brackish environments (Tappan \& Loeblich, 1968; Tenenbaum \& Gomes, 2006; Adamonis et al., 2007; Lipps et al., 2013). Among them, about 10 species are recorded from freshwater environments (Tappan \& Loeblich, 1968; Lipps et al., 2013).

In terms of biogeographical distribution, Dolan \& Pierce (2013) compartmentalized them into five biotas: (i) cosmopolitan; (ii) neritic; (iii) warm-water; (iv) boreal; and (v) austral, each biota involving species with distinct morphologies. Although they have a wide geographical distribution, tintinnids are subject to ecological restrictions, which control their abundance and diversity. In cold waters, assemblages are low in diversity and high in abundance, while in tropical waters diversity is higher but cells are smaller and less numerous.

In modern oceans, blooms of tintinnids seem to be strongly seasonally influenced (Armstrong \& Brasier, 2005; Dolan \& Pierce, 2013). Tintinnids with agglutinated and organic lorica are common in open sea and neritic environments (Lipps et al., 2013). Ecological studies have shown that many species of tintinnids are tolerant to large variations in salinity and water depth. Tintinnid species with agglutinated lorica preferentially inhabit the proximal environments and can serve as a good environmental indicator, suggesting brackish waters or, at least, a proximity to sites of freshwater discharge (Echols \& Fowler, 1973).

\section{Stratigraphy}

The stratigraphic record and phylogeny of this group still holds uncertainties and controversies. Possible occurrences of tintinnids in Proterozoic (Li et al., 2009) and Paleozoic (Cuviller \& Sacal, 1963) strata have been reported, but as these records were based on fragile evidence, they are questionable (Tappan \& Loeblich, 1968; Lipps et al., 2013). Remane (1971) proposed a phylogenetic relationship between tintinnids and calpionellids, due to the morphological similarity between the lorica of these two groups; but this hypothesis cannot be confirmed because no modern species of tintinnid is known to have a carbonate lorica (Lipps et al., 2013). On the other hand, Reid \& John (1981) suggested a relationship between tintinnids and chitinozoans, an incertae sedis organic microfossil recorded from the Ordovician to the Devonian. Adamonis et al. (2007) contested this relationship.

The oldest stratigraphic occurrence of tintinnids is dated to the Jurassic (Rüst, 1885), and based on the recognition and description of agglutinated loricae. According to Lipps 
et al. (2013), agglutinated loricae are abundant in the shallow, neritic waters of the Cretaceous mid-continental seaway that flooded a central corridor through the center of North America, from the Gulf of Mexico to the Arctic Ocean. There is a gap in the geological record of agglutinated loricae, after the Cretaceous, having been found again in the Upper Pleistocene (Echols \& Fowler, 1973; Lipps et al., 2013).

Records of organic walled remains of tintinnids in Pre-Quaternary deposits are scarce. The earliest known occurrences are from the Lower Triassic of Ireland and Israel (Van Waveren, 1994) and the Lower Cretaceous of France (Gorin \& Steffen, 1991). Although there are several gaps in the fossil record of this group, tintinnid organic remains are frequent only from Holocene marine deposits (Reid, 1975; Reid \& John, 1978; Grill et al., 2002; Roncaglia, 2004; Borromei \& Quattrocchio, 2001, 2007; Meckler et al., 2008; Mudie et al., 2010; Pienkowski et al., 2011, 2013), and may aid in understanding recent environmental changes (Grill et al., 2002; Roncaglia, 2004; Borromei \& Quattrocchio, 2001, 2007; Meckler et al., 2008; Mudie et al., 2010).

\section{STUDY AREA}

This study was developed from samples collected from a core (PSC-03) carried out along of the BR 101 highway $(\mathrm{km}$ 243 - South, Lat. 2753'22'S; Long. 48³9'04' W), in the Municipality of Palhoça, the State of Santa Catarina (SC), in southern Brazil. This core is located approximately $6 \mathrm{~km}$ from the modern coastline (Figure 1). The Municipality of Palhoça is inserted in the Central Sector of the CPSC, which is characterized by a Quaternary lagoon complex, comprising colluvial, alluvial, beach, paludal and eolian deposits (Horn Filho, 2003), mainly of Holocene age. In this sector, the coast presents South-North orientation (Figure 1). The CPSC comprises a series of geomorphological features and depositional facies represented by various sedimentary facies, under marine, transitional and continental influences. These controls are directly related to transgressive and regressive Quaternary sea-level cycles.

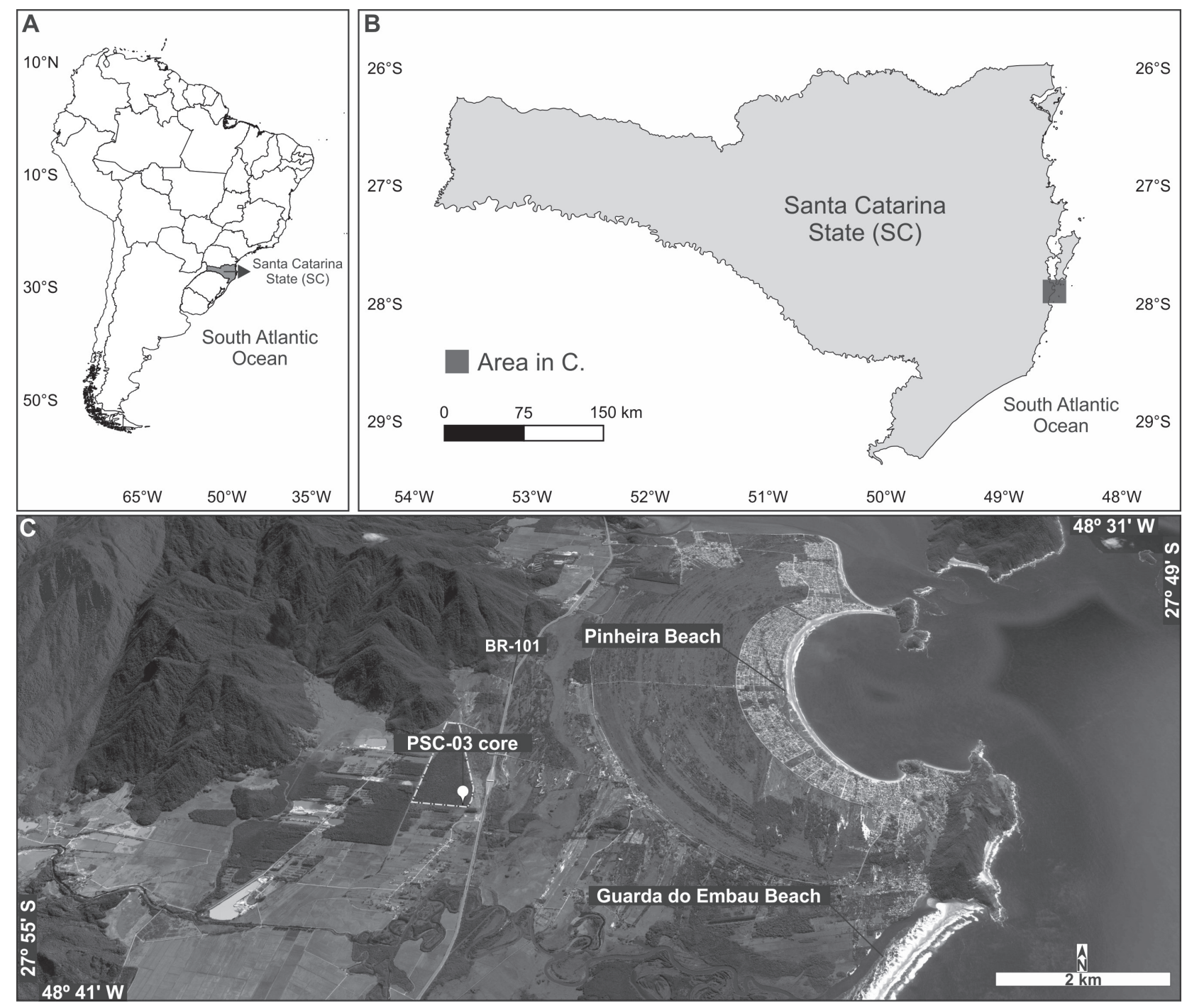

Figure 1. A-B, geographic localization of the studied core, in Santa Catarina, southern of Brazil. C, satellite image locating the core sample (PSC-03) site on the Coastal Plain of Santa Catarina (adapted from: Google Earth, 2017). 


\section{MATERIAL AND METHODS}

The $300 \mathrm{~cm}$ long of PSC-03 core consists of fine sand layers, intercalated with silt layers, bearing high organic content (Figure 2). Sixty palynological samples $\left(3 \mathrm{~cm}^{3}\right.$ each) were selected along the core, spaced $5 \mathrm{~cm}$ apart, which were processed at the Marleni Marques Toigo Palynology Laboratory, Department of Paleontology and Stratigraphy, Geosciences Institute, Universidade Federal do Rio Grande do Sul (LPMMT/IG/UFRGS). Laboratorial procedures are according to conventional method described by Wood et al. (1996) and following the Dale (1976) proposal, where each sample is treated with cold acids $(\mathrm{HCl}, \mathrm{HF})$, without oxidation and acetolysis are applied in order to prevent the loss of more fragile protoperidiniacean cysts. One tablet of Lycopodium clavatum was added in each sample to allow calculation of palynomorphs concentration (Stockmarr, 1971). Final residues were obtained by sieving. Slides were mounted using the fraction between 10 and $250 \mu \mathrm{m}$. Slides are stored in the LPMMT/IG/UFRGS collection under code "MP-P” (Figure 2). The material was studied and photomicrographs were taken under an Olympus BX61 optical light microscope. For each sample, percentages of the palynomorphs composition (spores, pollen grains, fungi, freshwater algae, dinoflagellate cysts, foraminiferal linings and tintinnomorphs) were calculated from the raw total counts (Table 1). Radiocarbon dating was obtained along the core, which was performed at the CAIS Laboratory (University of Georgia, USA), using Accelerator Mass Spectrometry (AMS). The program CALIB (Radiocarbon Calibration 7.1, Stuiver et al., 2016) was used for the calibration of these datings, considering the SHCal13 radiocarbon calibration curve (Southern Hemisphere, Hoog et al., 2013) (Table 2).

\section{RESULTS}

Most specimens recorded from the PSC-03 core were well preserved, allowing for the use of the descriptive system proposed by Van Waveren (1994). Tintinnomorphs occur in the majority of samples between $275 \mathrm{~cm}$ to $175 \mathrm{~cm}$ of depth, in varying amounts ( 1 to $5 \%$ ), always subordinated to the other palynological groups (spores-pollen, fungi, freshwater algae, foraminiferal linings, dinoflagellate cysts), except at $245 \mathrm{~cm}$ of depth, where they reached $14 \%$ of the total palynomorphs (Table 1). Six tintinnomorphs types were recorded; only one or two distinct types are represented per stratigraphic level (where they occur). ESABONO-6 and HEXANO-2 are the most frequent types.

Analysis of the descriptive system of tintinnomorphs types

The three main morphological structures of tintinnids are: (i) a lorica; (ii) a pouch attached to the aboral (basal) side of the lorica; (iii) a cyst encapsulated in the pouch (Van Waveren, 1994) (Figure 3A). Ideally, the cyst is encapsulated in the pouch, which in turn is inserted in the aboral portion of the lorica. However, the remains recovered from the palynological slides are dissociated, and are often misinterpreted, generically designated as lorica or cyst.

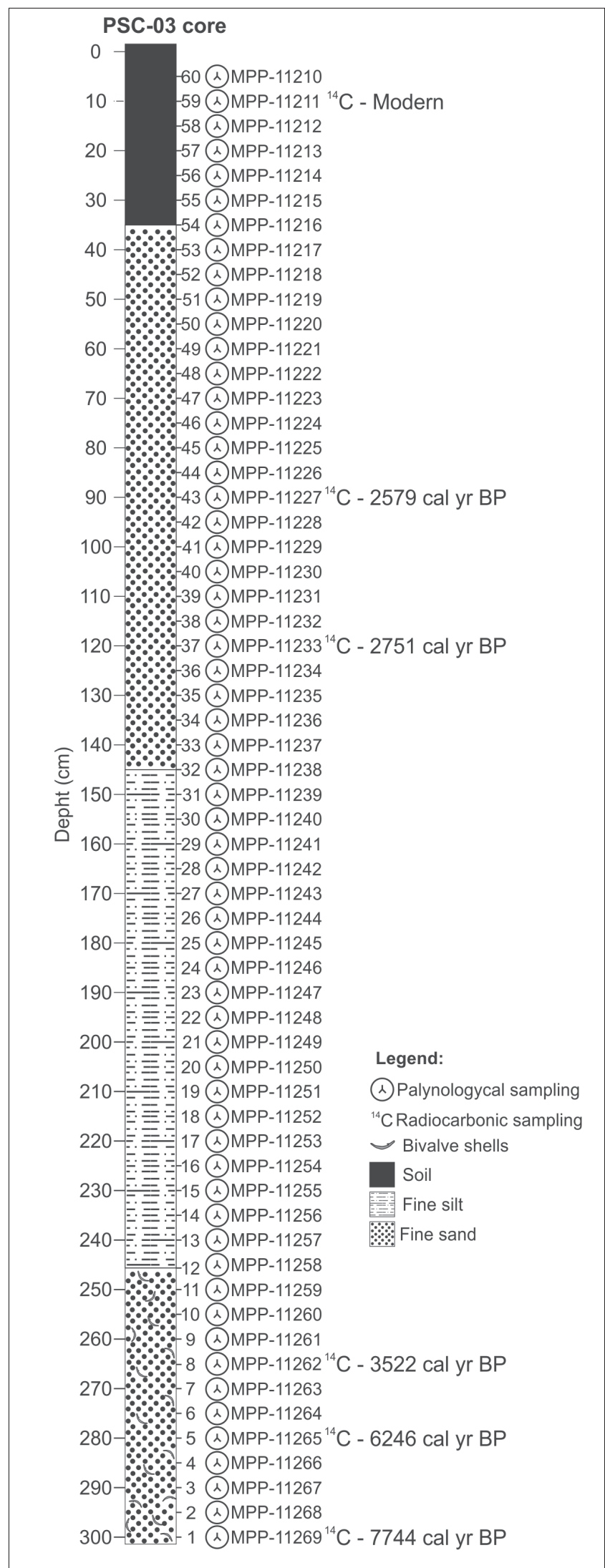

Figure 2. Stratigraphic column of the PSC-03 core, Holocene of the Coastal Plain of Santa Catarina, showing the position of palynological sampling, radiocarbon ages and list of palynological slides and their codification (the abbreviation MP-P concerns the slide collection of the LPMMT/IG/UFRGS). 
Table 1. Quantification of the palynomorphs recorded in the PCS-3 core (highlighted the levels where tintinnomorphs were found).

Abbreviations: a, counts; \%, relative frequencies.

\begin{tabular}{|c|c|c|c|c|c|c|c|c|c|c|c|c|c|c|c|}
\hline \multirow{2}{*}{$\begin{array}{l}\text { Depht } \\
\text { (cm) }\end{array}$} & \multicolumn{2}{|c|}{ Spores } & \multicolumn{2}{|c|}{ Pollen grains } & \multicolumn{2}{|c|}{ Fungi } & \multicolumn{2}{|c|}{ Fresh algae } & \multicolumn{2}{|c|}{$\begin{array}{l}\text { Dinoflagellate } \\
\text { cysts }\end{array}$} & \multicolumn{2}{|c|}{$\begin{array}{c}\text { Foraminiferal } \\
\text { linings }\end{array}$} & \multicolumn{2}{|c|}{ Tintinnomorphs } & \multirow{2}{*}{$\begin{array}{c}\text { Total } \\
\text { palynomorphs }\end{array}$} \\
\hline & (a) & $(\%)$ & (a) & $(\%)$ & (a) & $(\%)$ & (a) & $(\%)$ & (a) & $(\%)$ & (a) & $(\%)$ & (a) & $(\%)$ & \\
\hline 5 & 153 & 58 & 67 & 25 & 44 & 17 & 1 & 0 & 0 & 0 & 0 & 0 & 0 & 0 & 265 \\
\hline 10 & 144 & 53 & 92 & 34 & 34 & 13 & 0 & 0 & 0 & 0 & 0 & 0 & 0 & 0 & 270 \\
\hline 15 & 153 & 52 & 108 & 37 & 32 & 11 & 0 & 0 & 0 & 0 & 0 & 0 & 0 & 0 & 293 \\
\hline 20 & 116 & 32 & 157 & 43 & 74 & 20 & 20 & 5 & 0 & 0 & 0 & 0 & 0 & 0 & 367 \\
\hline 25 & 103 & 33 & 50 & 16 & 136 & 44 & 23 & 7 & 0 & 0 & 0 & 0 & 0 & 0 & 312 \\
\hline 30 & 69 & 24 & 22 & 8 & 183 & 63 & 17 & 6 & 0 & 0 & 0 & 0 & 0 & 0 & 291 \\
\hline 35 & 68 & 22 & 99 & 31 & 133 & 42 & 15 & 5 & 0 & 0 & 0 & 0 & 0 & 0 & 315 \\
\hline 40 & 40 & 12 & 199 & 61 & 78 & 24 & 8 & 2 & 0 & 0 & 0 & 0 & 0 & 0 & 325 \\
\hline 45 & 39 & 11 & 246 & 66 & 80 & 22 & 6 & 2 & 0 & 0 & 0 & 0 & 0 & 0 & 371 \\
\hline 50 & 79 & 21 & 173 & 46 & 118 & 31 & 5 & 1 & 0 & 0 & 0 & 0 & 0 & 0 & 375 \\
\hline 55 & 81 & 25 & 129 & 39 & 114 & 35 & 5 & 2 & 0 & 0 & 0 & 0 & 0 & 0 & 329 \\
\hline 60 & 116 & 41 & 96 & 34 & 40 & 14 & 29 & 10 & 0 & 0 & 0 & 0 & 0 & 0 & 281 \\
\hline 65 & 99 & 41 & 57 & 23 & 41 & 17 & 47 & 19 & 0 & 0 & 0 & 0 & 0 & 0 & 244 \\
\hline 70 & 103 & 45 & 45 & 19 & 39 & 17 & 44 & 19 & 0 & 0 & 0 & 0 & 0 & 0 & 231 \\
\hline 75 & 77 & 35 & 51 & 23 & 65 & 30 & 26 & 12 & 0 & 0 & 0 & 0 & 0 & 0 & 219 \\
\hline 80 & 42 & 14 & 34 & 12 & 208 & 71 & 7 & 2 & 0 & 0 & 0 & 0 & 0 & 0 & 291 \\
\hline 85 & 82 & 26 & 16 & 5 & 170 & 54 & 44 & 14 & 0 & 0 & 0 & 0 & 0 & 0 & 312 \\
\hline 90 & 32 & 12 & 10 & 4 & 188 & 69 & 41 & 15 & 0 & 0 & 0 & 0 & 0 & 0 & 271 \\
\hline 95 & 36 & 25 & 21 & 15 & 58 & 40 & 29 & 20 & 0 & 0 & 0 & 0 & 0 & 0 & 144 \\
\hline 100 & 26 & 21 & 24 & 19 & 41 & 33 & 34 & 27 & 0 & 0 & 0 & 0 & 0 & 0 & 125 \\
\hline 105 & 73 & 32 & 34 & 15 & 78 & 34 & 45 & 20 & 0 & 0 & 0 & 0 & 0 & 0 & 230 \\
\hline 110 & 45 & 29 & 17 & 11 & 64 & 42 & 28 & 18 & 0 & 0 & 0 & 0 & 0 & 0 & 154 \\
\hline 115 & 24 & 20 & 6 & 5 & 57 & 47 & 34 & 28 & 0 & 0 & 0 & 0 & 0 & 0 & 121 \\
\hline 120 & 31 & 21 & 14 & 9 & 60 & 41 & 43 & 29 & 0 & 0 & 0 & 0 & 0 & 0 & 148 \\
\hline 125 & 24 & 16 & 14 & 10 & 39 & 27 & 69 & 47 & 0 & 0 & 0 & 0 & 0 & 0 & 146 \\
\hline 130 & 30 & 13 & 14 & 6 & 77 & 34 & 107 & 47 & 0 & 0 & 0 & 0 & 0 & 0 & 228 \\
\hline 135 & 54 & 28 & 32 & 17 & 47 & 25 & 57 & 30 & 0 & 0 & 0 & 0 & 0 & 0 & 190 \\
\hline 140 & 44 & 27 & 26 & 16 & 63 & 38 & 33 & 20 & 0 & 0 & 0 & 0 & 0 & 0 & 166 \\
\hline 145 & 69 & 42 & 13 & 8 & 83 & 50 & 0 & 0 & 0 & 0 & 0 & 0 & 0 & 0 & 165 \\
\hline 150 & 38 & 44 & 15 & 17 & 32 & 37 & 0 & 0 & 1 & 1 & 1 & 1 & 0 & 0 & 87 \\
\hline 155 & 43 & 59 & 5 & 7 & 19 & 26 & 1 & 1 & 4 & 5 & 1 & 1 & 0 & 0 & 73 \\
\hline 160 & 46 & 62 & 1 & 1 & 4 & 5 & 0 & 0 & 21 & 28 & 2 & 3 & 0 & 0 & 74 \\
\hline 165 & 21 & 36 & 5 & 8 & 22 & 37 & 1 & 2 & 8 & 14 & 2 & 3 & 0 & 0 & 59 \\
\hline 170 & 44 & 54 & 16 & 20 & 5 & 6 & 0 & 0 & 15 & 18 & 2 & 2 & 0 & 0 & 82 \\
\hline 175 & 55 & 51 & 5 & 5 & 13 & 12 & 2 & 2 & 26 & 24 & 2 & 2 & 5 & 5 & 108 \\
\hline 180 & 41 & 71 & 3 & 5 & 7 & 12 & 0 & 0 & 3 & 5 & 2 & 3 & 2 & 3 & 58 \\
\hline 185 & 38 & 40 & 10 & 11 & 5 & 5 & 5 & 5 & 22 & 23 & 10 & 11 & 4 & 4 & 94 \\
\hline 190 & 19 & 46 & 2 & 5 & 3 & 7 & 0 & 0 & 16 & 39 & 1 & 2 & 0 & 0 & 41 \\
\hline 195 & 31 & 45 & 5 & 7 & 10 & 14 & 3 & 4 & 15 & 22 & 5 & 7 & 0 & 0 & 69 \\
\hline 200 & 24 & 44 & 4 & 7 & 11 & 20 & 0 & 0 & 11 & 20 & 2 & 4 & 3 & 5 & 55 \\
\hline 205 & 96 & 48 & 17 & 8 & 76 & 38 & 1 & 0 & 5 & 2 & 3 & 1 & 3 & 1 & 201 \\
\hline 210 & 51 & 51 & 14 & 14 & 12 & 12 & 0 & 0 & 16 & 16 & 2 & 2 & 5 & 5 & 100 \\
\hline 215 & 31 & 52 & 3 & 5 & 5 & 8 & 0 & 0 & 14 & 23 & 6 & 10 & 1 & 2 & 60 \\
\hline 220 & 24 & 28 & 18 & 21 & 20 & 23 & 1 & 1 & 20 & 23 & 3 & 3 & 0 & 0 & 86 \\
\hline 225 & 31 & 48 & 8 & 12 & 14 & 22 & 0 & 0 & 5 & 8 & 5 & 8 & 2 & 3 & 65 \\
\hline 230 & 31 & 58 & 4 & 8 & 8 & 15 & 0 & 0 & 4 & 8 & 4 & 8 & 2 & 4 & 53 \\
\hline
\end{tabular}


Table 1. Cont.

\begin{tabular}{|c|c|c|c|c|c|c|c|c|c|c|c|c|c|c|c|}
\hline \multirow{2}{*}{$\begin{array}{l}\text { Depht } \\
(\mathrm{cm})\end{array}$} & \multicolumn{2}{|c|}{ Spores } & \multicolumn{2}{|c|}{ Pollen grains } & \multicolumn{2}{|c|}{ Fungi } & \multicolumn{2}{|c|}{ Fresh algae } & \multicolumn{2}{|c|}{$\begin{array}{l}\text { Dinoflagellate } \\
\text { cysts }\end{array}$} & \multicolumn{2}{|c|}{$\begin{array}{l}\text { Foraminiferal } \\
\text { linings }\end{array}$} & \multicolumn{2}{|c|}{ Tintinnomorphs } & \multirow{2}{*}{$\begin{array}{c}\text { Total } \\
\text { palynomorphs }\end{array}$} \\
\hline & (a) & $(\%)$ & (a) & $(\%)$ & (a) & $(\%)$ & (a) & $(\%)$ & (a) & $(\%)$ & (a) & $(\%)$ & (a) & $(\%)$ & \\
\hline 235 & 27 & 47 & 2 & 4 & 10 & 18 & 0 & 0 & 14 & 25 & 3 & 5 & 1 & 2 & 57 \\
\hline 240 & 13 & 52 & 1 & 4 & 4 & 16 & 0 & 0 & 4 & 16 & 3 & 12 & 0 & 0 & 25 \\
\hline 245 & 17 & 39 & 7 & 16 & 4 & 9 & 0 & 0 & 6 & 14 & 4 & 9 & 6 & 14 & 44 \\
\hline 250 & 30 & 61 & 7 & 14 & 3 & 6 & 0 & 0 & 3 & 6 & 5 & 10 & 1 & 2 & 49 \\
\hline 255 & 25 & 44 & 10 & 18 & 7 & 12 & 0 & 0 & 5 & 9 & 10 & 18 & 0 & 0 & 57 \\
\hline 260 & 17 & 26 & 18 & 27 & 10 & 15 & 1 & 2 & 14 & 21 & 3 & 5 & 3 & 5 & 66 \\
\hline 265 & 35 & 40 & 21 & 24 & 18 & 20 & 2 & 2 & 4 & 5 & 6 & 7 & 2 & 2 & 88 \\
\hline 270 & 24 & 32 & 19 & 25 & 9 & 12 & 1 & 1 & 17 & 22 & 5 & 7 & 1 & 1 & 76 \\
\hline 275 & 15 & 56 & 3 & 11 & 5 & 19 & 0 & 0 & 0 & 0 & 3 & 11 & 1 & 4 & 27 \\
\hline 280 & 15 & 27 & 12 & 22 & 2 & 4 & 0 & 0 & 23 & 42 & 3 & 5 & 0 & 0 & 55 \\
\hline 285 & 21 & 36 & 10 & 17 & 11 & 19 & 0 & 0 & 14 & 24 & 2 & 3 & 0 & 0 & 58 \\
\hline 290 & 11 & 48 & 5 & 22 & 3 & 13 & 0 & 0 & 2 & 9 & 2 & 9 & 0 & 0 & 23 \\
\hline 295 & 19 & 36 & 7 & 13 & 11 & 21 & 0 & 0 & 14 & 26 & 2 & 4 & 0 & 0 & 53 \\
\hline 300 & 12 & 32 & 14 & 38 & 10 & 27 & 0 & 0 & 1 & 3 & 0 & 0 & 0 & 0 & 37 \\
\hline
\end{tabular}

Table 2. AMS ${ }^{14} \mathrm{C}$ and calibrated ages of selected samples (using CALIB 7.1; Stuiver et al., 2016) from the PSC-03 core. * ${ }^{*}$ MC is the percentage of modern carbon relative to the modern reference, is presented when the analyzed material has more ${ }^{14} \mathrm{C}$ that the modern reference, this sample is indicating a post bomb (Modern).

\begin{tabular}{|c|c|c|c|c|c|}
\hline $\begin{array}{l}\text { Laboratory } \\
\text { reference }\end{array}$ & $\begin{array}{l}\text { Depht } \\
(\mathrm{cm})\end{array}$ & $\begin{array}{l}{ }^{14} \mathrm{C} \text { age } \\
\mathrm{BP}\end{array}$ & $\begin{array}{c}\text { Age } \\
\text { (cal yr BP 2 })\end{array}$ & $\begin{array}{l}\text { Mean calibrated age } \\
\quad \text { (cal yr. BP) }\end{array}$ & Material \\
\hline UGAMS \# 25848 & 10 & $100.85 \pm 0.30 * \mathrm{pMC}$ & Modern & ---- & sediment \\
\hline UGAMS \# 26518 & 90 & $2520 \pm 25$ & $2426-2721$ & 2579 & wood \\
\hline UGAMS \# 26983 & 120 & $2660 \pm 20$ & $2723-2777$ & 2751 & sediment \\
\hline UGAMS \# 26517 & 265 & $3340 \pm 25$ & $3598-3607$ & 3522 & sediment \\
\hline UGAMS \# 26982 & 280 & $5490 \pm 25$ & $6195-6299$ & 6246 & sediment \\
\hline UGAMS \# 22214 & 300 & $6960 \pm 30$ & $7676-7832$ & 7744 & sediment \\
\hline
\end{tabular}

The descriptive key proposed by Van Waveren (1994) is based on the morphological characterization of tintinnid organs, but the proposed types are designated as tintinnomorphs. Moreover, these features are named with different terms from those used for tintinnids, in order to avoid a direct attribution to the latter. In this way, the six main features are: (i) a corolla enclosing a chamber; (ii) an opening (sometimes with operculum); (iii) a calyx (a hollow appendix); (iv) a stem (a massive appendix); (v) a horn (calyx plus stem) and (vi) a collar (Figure 3B). Variations in shape, surface structure (ornamentation), presence, number and type of stems, opening position, shape and ornamentation of collar are the parameters used in the classification criteria (Figures 3C-K).

Because the thickness of the wall may reflect the organism's life cycle (Van Waveren, 1994), this characteristic was not used as a classification criterion. Size and color were not used as a classification criterion for tintinnomorphs either. A total of eleven main types of tintinnomorphs can be recognized by means of this description: (1) spherical (“SPHER"); (2) elliptical (“ELLIP”); (3) elongated elliptical
("ELEL"); (4) egg-shape, aborally blunt ("ESAB"); (5) eggshape, orally blunt ("ESOB"); (6) hexagonal ("HEXA"); (7) rectangular ("RECT"); (8) asymmetrically rhombic, aborally blunt (“ARAB”); (9) asymmetrically rhombic, orally blunt ("AROB"); (10) triangular ("TRIA"); (11) tetragonal ("TETRA").

At the end of each coding, an indication for the presence $(\mathrm{O})$ or the absence $(\mathrm{NO})$ of ornamentation is given, as well as, a final number $(1,2, n . .$.$) identifying differences within$ the morphotypes.

\section{SYSTEMATIC AND DESCRIPTION OF TINTINNOMORPHS TYPES}

Six tintinnomorphs types were described according to their morphological features. The recognized types are SPHERO-1, ELELNO-14, ESABNO-6, HEXANO-2, RECTNO-1 and AROBNO-3 (Figure 4). Although the size of the tintinnomorphs is not a classification criterion, it is worth mentioning that these specimens presented average measurements of $170 \mu \mathrm{m}$ in length per $100 \mu \mathrm{m}$ wide. 


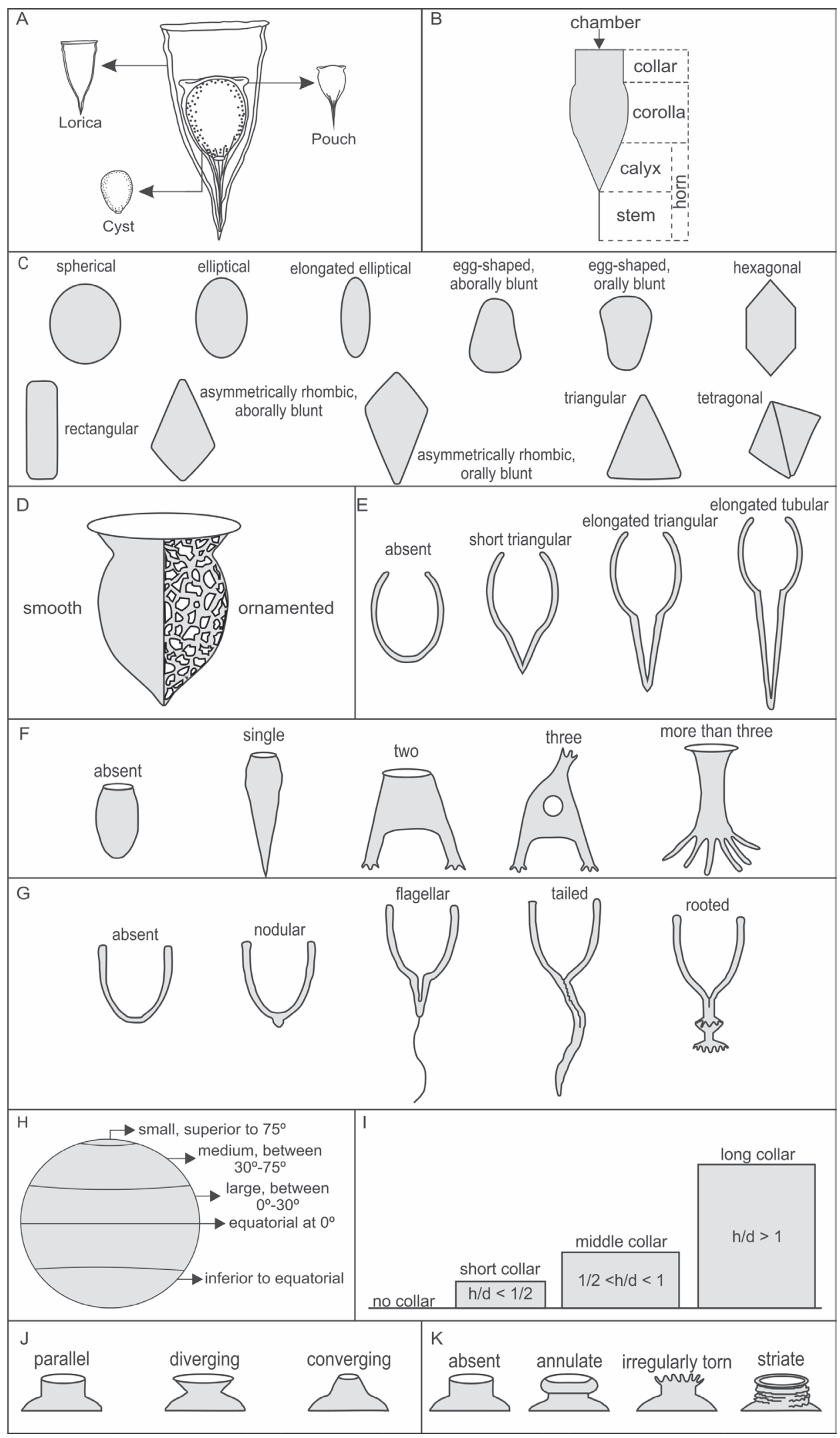

Figure 3. General framework of classification criteria: A, three different categories of organic remains assignable to tintinnids: a lorica, a pouch attached to the aboral (basal) side of the lorica, a cyst encapsulated in the pouch; $\mathbf{B}$, main features of tintinnomorphs: a corolla enclosing a chamber, an opening (sometimes with operculum), a calyx (a hollow appendix), a stem (a massive appendix), a horn (calyx plus stem), a collar; $\mathbf{C}$, shapes of the corolla of tintinnomorphs; $\mathbf{D}$, surface structures of tintinnomorphs; $\mathbf{E}$, shapes of the calyx of tintinnomorphs; $\mathbf{F}$, presence and number of stems of tintinnomorphs; $\mathbf{G}$, types of stems of tintinnomorphs; $\mathbf{H}$, distinct positions of the opening in tintinnomorphs; I, collar elongation of tintinnomorphs defined by the ratio between its height and its diameter ( $h / d)$; J, collar shapes of tintinnomorphs; $\mathbf{K}$, collar ornamentation of tintinnomorphs. All the figures have been modified from Van Waveren (1994). 


\section{SPHERO-1}

(Figure 4A)

Description. One specimen: tintinnomorph of spherical shape ornamented, without calyx, without stem, opening large (equatorial), no collar.

Occurrence. Depth of $265 \mathrm{~cm}$.

Comment. Specimens of tintinnomorph type SPHERO were recorded from modern surface sediments of the Banda Sea, Indonesia (Van Waveren, 1994).

\section{ELELNO-14}

(Figure 4B)

Description. One specimen: tintinnomorph elongated with triangular calyx, not ornamented, tailed stem, no collar, opening inferior to equatorial.

Occurrence. Depth of $250 \mathrm{~cm}$.

Comment. Specimens of tintinnomorph type ELELNO were recorded from modern surface sediments of the Banda Sea, Indonesia (Van Waveren, 1994). Oliveira (2003) reported specimens similar to tintinnomorph type ELELNO, identified as worm eggs, from Pleistocene marine environment of Campos Basin (Brazil). Matsuoka et al. (2017) reported specimens assigned to the type ELELNO-13 (sensu Van Waveren, 1994) from modern marine deposits in Asia.

\section{ESABNO-6}

(Figures 4C-E)

Description. Six specimens: tintinnomorph egg-shaped, aborally blunt type, not ornamented, without calyx, without stem, rooted stem, opening medium (between $30^{\circ}-75^{\circ}$ ).

Occurrence. Depth of 260, 255, 250, 200, 185 and $175 \mathrm{~cm}$. Comment. Specimens of tintinnomorph type ESABNO were recorded from modern surface sediments of the Banda Sea, Indonesia (Van Waveren, 1994). Stancliffe \& Matsuoka (1991) reported a specimen similar to tintinnomorph type ESABNO. This specimen was identified as? Domasiella sp. (acritarch), from Holocene marine sediments, off coast of northwestern Kyushu (Japan). Sparica et al. (2005) reported specimens similar to tintinnomorph type ESABNO, identified as tintinnid chitinous loricae, from Holocene shallow-marine environment of northern Dalmatia (Croatia).

\section{RECTNO-1}

(Figure 4F)

Description. Two specimens: tintinnomorph rectangular type, not ornamented, without calyx, without stem, opening equatorial and no collar.

Occurrence. Depth of 225 and $185 \mathrm{~cm}$.

Comment. Specimens of tintinnomorph type RECTNO were recorded from modern surface sediments of the Banda Sea, Indonesia (Van Waveren, 1994).

HEXANO-2

(Figures 4G-H)
Description. Six specimens: tintinnomorph hexagonal type, not ornamented, with small calyx, without stem, opening large, no collar.

Occurrence. Depth of 275, 235, 215, 210 and $205 \mathrm{~cm}$.

Comment. Similar specimens to tintinnomorphs included in type HEXA have been recorded from middle to late Holocene sediments with marine influence of CPRS in Capão do Leão (Neves \& Bauermann, 2001, 2003); from Upper Pleistocene to Holocene sediments of Pirataba and Faxinal (Roth \& Lorcheistter, 2016); from Holocene brackish swamp deposits sediments of CPSC, in São João do Sul (Cancelli et al., 2012), identified as remains of flatworm eggs. Holocene marine sediments from Lapatia Bay (Beagle Channel, Argentina), Borromei \& Quatrocchio (2001) found a specimen similar to the tintinnomorph HEXANO-3 (sensu Van Waveren, 1994), identified as tintinnid lorica. Mudie et al. (2011) recorded specimens related to the tintinnomorph HEXANO-2 from Holocene marine deposits of the Marmara Sea (Turkey), identified as tintinnid lorica or Turbellaria Class worm egg capsule.

\section{AROBNO-3}

(Figure 4I)

Description. One specimen: tintinnomorph asymmetrically rhombic, orally blut, not ornamented, without calyx, without stem, with more than three tail-like stems, opening medium, middle to long diverging collar, no collar ornamentation.

Occurrence. Depth of $265 \mathrm{~cm}$.

Comment. Similar specimens to tintinnomorphs, included in type AROB, were recorded from marine fine-grained carbonates deposit of the Early Cretaceous (Berriasian) of France (Gorin \& Steffen, 1991), identified as tintinnids (sensu Reid \& John, 1981) or single chamber foraminiferal linings (sensu Stancliffe, 1989).

\section{TINTINNOMORPHS: ENVIRONMENTAL SIGNATURE}

In modern marine sediments, tintinnomorphs always are subordinated to others marine palynomorphs (dinoflagellate cysts, acritarchs, foraminifera linings and copepod eggs) (Kawamura, 2004; Hardy \& Wrenn, 2009; Matsuoka et al., 2017). Kawamura (2004) suggests that the concentration of the tintinnomorphs in sediments is inversely correlated to the depth of the water column.

Tintinnomorphs were found as an accessory element of the zooplankton component of palynomorph association from the outer shelf to lower continental slope of the Sunda Shelf, South China Sea. The tintinnomorphs were recorded in all sites of transect, but presented better concentrations from the inner shelf and slope palynological assemblage (Kawamura, 2004). The occurrences of tintinnomorphs in slope assemblages suggest a mixed signal of estuary high productivity species and oceanic low productivity species. This mixed signal is resulting by transport processes of the circulation of seafloor bottoms (Kawamura, 2004). 

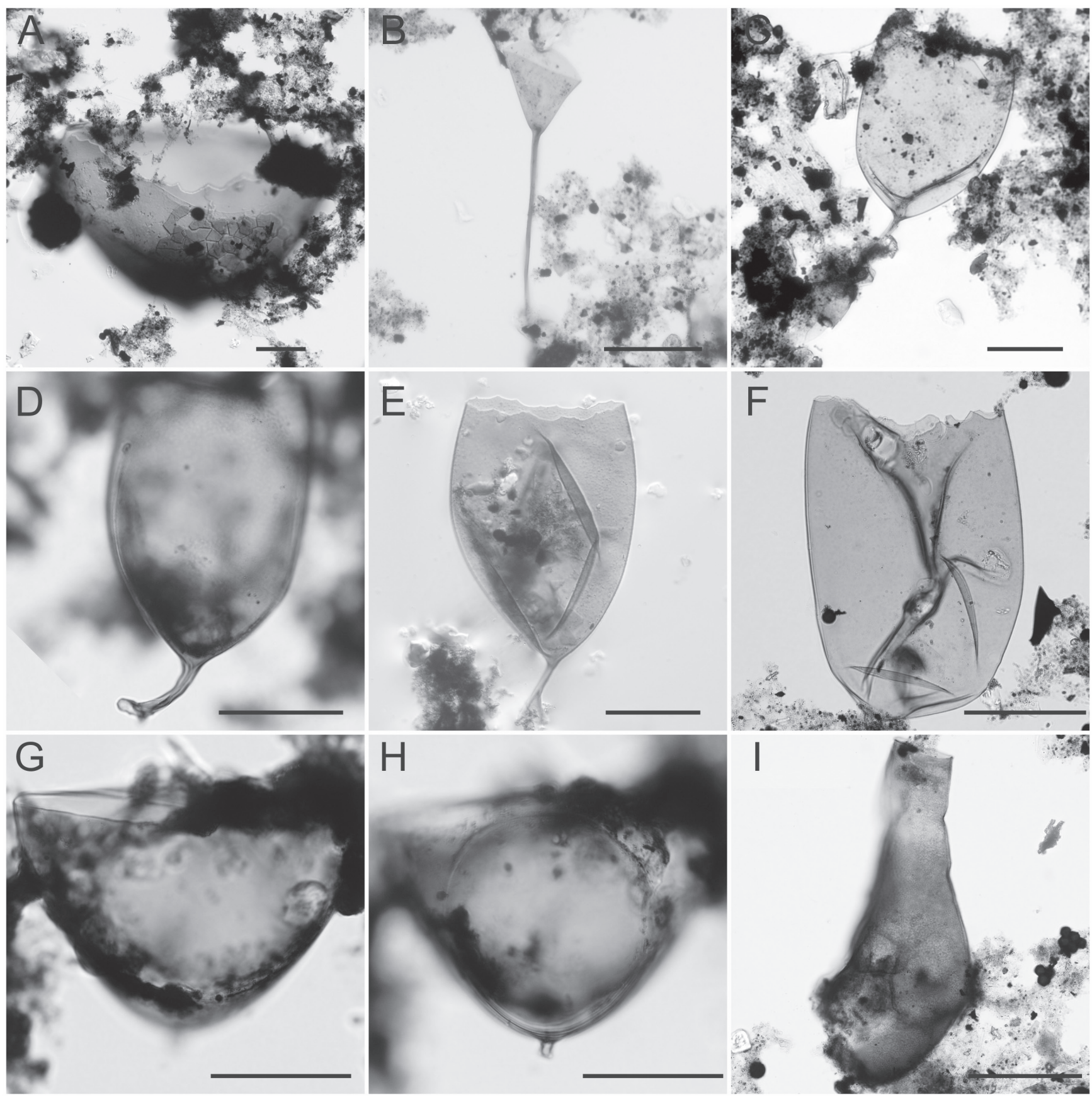

Figure 4. Photomicrographs of tintinnomorphs recorded from the PSC-03 core. A, SPHERO-1 (slide MPP: 11262, England Finder: K35); B ELELNO-14 (11258, T46); C-E, ESABNO-6 (11245, G45-4), (11244, C57-4), (11249, W31-4); F, RECTNO-1 (11246, B52); G-H, HEXANO-2 (11251, D35-2); I, AROBNO-3 (11262, E37-2). Scale bars $=50 \mu \mathrm{m}$.

Preservation of tintinnomorphs in sediments may be related to the combined effect of high productivity and high sedimentation rates in the depositional site (Van Waveren, 1994; Van Waveren \& Visscher, 1994). Hardy \& Wrenn (2009) studying the palynomorph distribution in modern deltaic and shelf sediments of the Mahakam delta (Borneo), recorded a low quantity and variety of tintinnomorphs, however this low concentration was also verified in dinoflagellate cysts.

In palynological assemblages in South America, where they were reported, paleoenvironmental interpretations are implying marginal marine conditions with high input of continental organic matter (Grill et al., 2002; Borromei \& Quattrocchio, 2001, 2007). According to Roncaglia (2004), the increase of tintinnid loricae, dinoflagellate cysts concentration, planktonic crustacean eggs as well as structured brown phytoclasts, plant tissue and sporomorphs from Holocene sediments of the Skálafjord (Faroe Islands) were related to the increase of primary productivity in the waters of the fjord. For Mudie et al. (2010, 2011), in restricted marine basins, such as Black and Caspian Sea, the literature on living equivalents of the tintinnids suggests that nutrients are probably more important than salinity for the blooms. 
During a combined optical and biomarker analysis of Holocene sediments of the Gulf of Mexico, Meckler et al. (2008) identified tintinnid loricae in excellent state of preservation, associated with chitinous crustacean remains and dinoflagellate cysts. In this case, the alternation of levels with marine palynomorphs (tintinnid loricae, crustacean remains and dinoflagellate cysts) with those ones of terrestrial palynomorphs (pollen grains and spores) was resulting from the interference of climatic and ecological oscillations.

\section{FINAL REMARKS}

The tintinnomorphs recorded in the PSC-03 core are associated with terrestrial (spores, pollen grains, fungi and freshwater algae) and marine (dinoflagellate cyst, foraminifera linings) palynomorphs. They become absent from levels where marine palynomorphs show a tendency of scarcity or are absent (Table 1).

Samples from the PSC-03 core where tintinnomorphs occur also bear dinoflagellate cysts of the genera Brigantedinium, Lejeunecysta, Operculodinium, Spiniferites, Selenopemphix besides foraminifera linings. All these taxa are reliable indicators of marine conditions, suggesting that the depositional site area was influenced by marine water.

The inference of marine incursion over Coastal Plains is supported by other studies on the coastal plain of Santa Catarina (Behling \& Negrelli, 2001; Amaral et al., 2012; Angulo et al., 2006; Kuhn et al., 2017), as well as in Coastal Plain of Rio Grande do Sul (Lorscheitter \& Dillenburg, 1998; Meyer et al., 2005; Medeanic et al., 2009). Similarly, the Coastal Plain of the South Atlantic margin of South America offers further environmental proxies (Martínez \& Rojas, 2013; Mourelle et al., 2015; Candel \& Borromei, 2016).

The scarcity of systematic studies on tintinnomorphs as well as the uncertainties on their biological affinity impairs the use of this organic-walled microfossil for paleoenvironmental interpretations; the analysis considering the total fossil association can elucidate this issue. The morphological system proposed by Van Waveren (1994) has proved to be effective in the initial characterization of these fossil organic structures, since it allows their characterization in an artificial grouping. This bars the controversial classification of palynomorphs as lorica, cyst or pouch that has been observed in previous studies.

\section{ACKNOWLEDGMENTS}

The authors would like to thank the Coordenação de Aperfeiçoamento de Pessoal de Nível Superior (CAPES) for the basic research project funding; the Fundação de Amparo à Pesquisa do Estado do Rio Grande do Sul (FAPERGS, proc. 1012119) for complementary funding; the support of the Instituto Federal do Rio Grande do Sul, through its Human Resources Training Program (IFRS proc. 23367002207201550 ); and R. B. Braga for reviewing this manuscript and figures; editor M.J. Garcia and anonymous reviewers for revision, suggestions and comments the manuscript. This paper is an integral part of the doctoral thesis of the first author.

\section{REFERENCES}

Adamonis, S.; Concheyro, A. \& Alder, V. 2007. Protistas autótrofos y heterótrofos: silicoflagelados, ebridianos y tintinídos. In: H.H. Camacho \& M.I. Longobucco (eds.) Los Invertebrados Fósiles Tomo I, Fundación de Historia Natural Félix de Azara, p. 133-145.

Agatha, S. \& Strüder-Kypke, M.C. 2013. Systematics and evolution of tintinnid ciliates. In: J.R. Dolan; J.S.M. David; S. Agatha; D.C. Wayne \& K.S. Diane (eds.) The biology and ecology of tintinnid ciliates: models for marine plankton, John Wiley \& Sons, p. 42-84. doi:10.1002/9781118358092.ch3

Amaral, P.G.C.; Giannini, P.C.F.; Sylvestre, F. \& Pessenda, L.C.R. 2012. Paleoenvironmental reconstruction of a Late Quaternary lagoon system in southern Brazil (Jaguaruna region, Santa Catarina state) based on multi-proxy analysis. Journal of Quaternary Science, 27:181-191. doi:10.1002/jqs.1531

Angulo, R.J.; Lessa, G.C. \& Souza, M.C. 2006. A critical review of mid- to late-Holocene sea-level fluctuations on the eastern Brazilian coastline. Quaternary Science Reviews, 25:486-506. doi:10.1016/j.quascirev.2005.03.008

Armstrong, H.A. \& Brasier, M.D. 2005. Microfossils. $2^{\text {nd }}$ ed. Oxford, Blackwell, 296 p.

Barnes, R.D. 1990. Zoologia dos invertebrados. $4^{\mathrm{a}}$ ed. São Paulo, Roca, 1179 p.

Behling, H. \& Negrelle, R.R.B. 2001. Tropical rain forest and climate dynamics of the atlantic lowland, Southern Brazil, during the Late Quaternary. Quaternary Research, 56:383-389. doi:10.1006/qres.2001.2264

Borromei, A.M. \& Quattrocchio, M. 2001. Palynological study of Holocene marine sediments from Bahia Lapataia, Beagle channel, Tierra del Fuego, Argentina. Revista Española de Micropaleontologia, 33:61-70.

Borromei, A.M. \& Quattrocchio, M. 2007. Holocene sea-level changes inferred from palynological data in the Beagle channel, Southern Tierra del Fuego, Argentina. Ameghiniana, 44:161-171.

Cancelli, R.R.; Souza, P.A. \& Neves, P.C.P. 2012. Fungos, criptógamas e outros palinomorfos holocênicos $(7908 \pm 30$ anos AP-atual) da Planície Costeira sul-catarinense, Brasil. Acta Botanica Brasilica, 26:20-37. doi:10.1590/S010233062012000100004

Candel, M.S. \& Borromei, A.M. 2016. Review of the paleoenvironmental reconstruction of Late Quaternary marine sequences, Tierra Del Fuego (Argentina). In: M. Martínez \& D. Olivera (eds.) Palinología del Meso-Cenozoico de Argentina, Buenos Aires, Asociación Paleontológica Argentina, p. 184-201 (Publicación Electrónica 16). doi:10.5710/ PEAPA.16.08.2016.112

Canudo, J.I. 2004. Tintínidos. In: E. Molina (ed.) Micropaleotología, Prensas Universitarias de Zaragoza, 293 p.

Cuvillier, J. \& Sacal, V. 1963. Presence de tintinnoidiens dans le Devoinian Superieur du Sahara septronial. Revue de Micropaleontologie, 6:73-75.

Dale, B. 1976. Cyst formation, sedimentation and preservation: factors affecting dinoflagellate assemblages in recent sediments from Trondheimsfjord, Norway. Review of Palaeobotany and Palynology, 22:39-60. doi:10.1016/0034-6667(76)90010-5

Dolan, R.D. \& Pierce, R.W. 2013. Diversity and distributions of tintinnids. In: J.R. Dolan; J.S.M. David; S. Agatha; D.C. Wayne \& K.S. Diane (eds.) The biology and ecology of tintinnid ciliates: models for marine plankton, John Wiley \& Sons, p. 214-243. doi:10.1002/9781118358092.ch10 
Echols, R.J. \& Fowler, G.A. 1973. Agglutinated tintinnid loricae from some Recent and Late Pleistocene shelf sediments. Micropaleontology, 19:431-443. doi:10.2307/1484906

Gorin, G.E. \& Steffen, D. 1991. Organic facies as a tool for recording eustatic variations in marine fine-grained carbonates example of the Berriasian stratotype at Berrias (Ardèche, SE France). Palaeogeography, Palaeoclimatology, Palaeoecology, 85:303-320. doi:10.1016/0031-0182(91)90164-M

Grill, S.; Borromei, A.M.; Quattocchio, M.; Coronato, A.; Bujalesky, G. \& Rabassa, J. 2002. Palynological and sedimentological analysis of recente sediments from Rio Varela, Beagle channel, Tierra del Fuego, Argentina. Revista Española de Micropaleontologia, 34:145-161.

Hardy, M.J. \& Wrenn, J.H. 2009. Palynomorph distribution, deltaic and shelf sediments, Mahakam delta, Borneo, Indonesia. Palynology, 33:19-42. doi:10.2113/gspalynol.33.2.19

Hogg, A.G.; Hua, Q.; Blackwell, P.G.; Niu, M.; Buck, C.E.; Guilderson, T.P.; Heaton, T.J.; Palmer, J.G.; Reimer, P.J.; Reimer, R.W.; Turney, C.S.M. \& Zimmerman, S.R.H. 2013. SHCal13 Southern Hemisphere Calibration, 0-50,000 Years cal BP. Radiocarbon, 55:1889-1903. doi:10.2458/azu js_rc.55.16783

Horn Filho, N.O. 2003. Setorização da província costeira de Santa Catarina, em base aos aspectos geológicos, geomorfológicos e geográficos. Geosul, 37:45-78.

Kawamura, H. 2004. Dinoflagellate cyst distribution a long a shelf to slope transect of an oligotrophic tropical sea (Sunda Shelf, South China Sea). Phycological Research, 52:355-375. doi: 10.1111/j.1440-183.2004.00362.x

Kuhn, L.A.; Souza, P.A.; Cancelli, R.R.; Silva, W.G. \& Macedo, R.B. 2017. Paleoenviromental evolution of the coastal plain of southern Brazil: palynological data from a Holocene core in Santa Catarina state. Anais da Academia Brasileira de Ciências, 89:2581-2595. doi:10.1590/0001-3765201720160895

Li, Y.X.; Zhang, S.X. \& Zhang, J. 2009. Mesoproterozoic calymmian tintinnids from central China. The Open Paleontology Journal, 2:10-13. doi:10.2174/1874425700902010010

Lipps, J.H.; Stoeck, T. \& Dunthorn, M. 2013. Fossil tintinnids. In: J.R. Dolan; J.S.M. David; S. Agatha; D.C. Wayne \& K.S. Diane (eds.) The biology and ecology of tintinnid ciliates: models for marine plankton, John Wiley \& Sons, p. 186-197. doi:10.1002/9781118358092.ch8

Lorscheitter, M.L. \& Dillenburg, S.R. 1998. Holocene paleoenvironments of the northern coastal plain of Rio Grande do Sul, Brazil, reconstructed from palynology of Tramandaí lagoon sediments. Quaternary of South America and Antarctic Peninsula, 11:73-97.

Martínez, S. \& Rojas, A. 2013. Relative seal level during the Holocene in Uruguay. Palaeogeography, Palaeoclimatology, Palaeoecology, 374:123-131. doi:10.1016/j.palaeo.2013.01.010

Matsuoka, K.; Yurimoto, T.; Chong, V.C. \& Man, A. 2017. Marine palynomorphs dominated, by heterotrophic organism remains in tropical coastal shallow-water sediment; the case of Selangor coast and the estuary of the Manjung river in Malaysia. Paleontological Research, 21:14-26. doi:10.2517/2016PR006

Meckler, A.N.; Schubert, C.J.; Hochuli, P.A.; Plessen, B.; Birgel, D.; Flower, B.P.; Hinrichs, K.U. \& Haug, G.H. 2008. Glacial to Holocene terrigenous organic matter input to sediments from Orca Basin, Gulf of Mexico - A combined optical and biomarker approach. Earth and Planetary Science Letters, 272:251-263. doi:10.1016/j.epsl.2008.04.046

Medeanic, S.; Torgan, L.C.; Clerot, L.C.P. \& Santos, C.B. 2009. Holocene marine transgression in the Coastal Plain of Rio
Grande do Sul, Brazil: palynomorph and diatom evidence. Journal of Coastal Research, 25:224-233. doi:10.2112/070935.1

Meyer, K.E.B.; Mendonça Filho, J.G.; Ashraf, A.R.; Souza, P.A. \& Reichart, K. 2005. Análise de palinofácies em sedimentos holocênicos da Lagoa dos Quadros, Planície Costeira do Rio Grande do Sul, Brasil. Revista Brasileira de Paleontologia, 8:57-72.

Mourelle, D.; Prieto, A.R.; Pérez, L.; García-Rodríguez, F. \& Borel, M.C. 2015. Mid and late Holocene multiproxy analysis of environmental changes linked to sea-level fluctuation and climate variability of the Río de la Plata estuary. Palaeogeography, Palaeoclimatology, Palaeoecology, 421:75-88. doi:10.1016/j. palaeo.2015.01.006

Mudie, P.J.; Leroy, S.A.G.; Marret, F.; Gerasimenko, N.P.; Kholeif, S.E.A.; Sapelko, T. \& Filipova-Marinova, M. 2011. Nonpollen palynomorphs: indicators of salinity and environmental change in the Caspian-Black Sea-Mediterranean corridor In: I.V. Buynevich; V. Yanko-Hombach; A.S. Gilbert \& R.E. Martin (eds.) Geology and geoarchaeology of the Black Sea region: beyond the flood hypothesis, Bolder, Geological Society of America, $\mathrm{p}$. 89-115 (Special Paper 473). doi:10.1130/2011.2473(07)

Mudie, P.J.; Marret, F.; Rochon, A. \& Aksu, A.E. 2010. Non-pollen palynomorphs in the Black Sea corridor. Vegetation History and Archaeobotany, 19:531-544. doi:10.1007/s00334-010-0268-9

Neves, P.C.P. \& Bauermann, S.G. 2001. Feições de uma mata de restinga em Capão do Leão, planície costeira do Sul, Rio Grande do Sul, Brasil. Pesquisas, Série Botânica, 51:73-86.

Neves, P.C.P. \& Bauermann, S.G. 2003. Catálogo palinológico de coberturas quaternárias do estado do Rio Grande do Sul (Guaíba e Capão do Leão), Brasil. Descrições taxonômicas Parte - I: fungos, algas, palinomorfos outros e fragmentos de invertebrados. Pesquisas, Série Botânica, 53:121-149.

Oliveira, A.D. 2003. Reconstrução paleoambiental com base nas assembleias de dinoflagelados presentes nos sedimentos do Holoceno e Pleistoceno do talude continental brasileiro da Bacia de Campos, RJ-Brasil. Programa de Pós-Graduação em Geociências, Instituto de Geociências, Universidade Federal do Rio de Janeiro, Dissertação Mestrado, 198 p.

Pienkowski, A.J.; Marret, F.; Scourse, J.D. \& Thomas, D.N. 2013. Organic-walled microfossils from the north-west Weddell Sea, Antarctica: records from surface sediments after the collapse of the Larsen-A and Prince Gustav Channel ice shelves. Antarctic Science, 25:565-574. doi:10.1017/S0954102012001186

Pienkowski, A.J.; Mudie, P.J.; England, J.H.; Smith, J.N. \& Furze, M.F. 2011. Late Holocene environmental conditions in Coronation Gulf, southwestern Canadian Arctic Archipelago: evidence from dinoflagellate cysts, other non-pollen palynomorphs, and pollen. Journal of Quaternary Science, 26:839-853. doi:10.1002/ jqs. 1503

Reid, P.C. 1975. A regional sub-division of dinoflagellate cysts around the British Isles. New Phytologist, 75:589-603. doi:10.1111/j.1469-8137.1975.tb01425.x

Reid, P.C. \& John, A.W.G. 1978. Tintinnid cysts. Marine Biological Association of the United Kingdom, 58:551-557. doi:10.1017/ S0025315400041205

Reid, P.C. \& John, A.W.G. 1981. A possible relationship between chitinozoa and tintinnids. Review of Palaeobotany and Palynology, 34:251-262. doi:10.1016/0034-6667(81)90043-9

Remane, J. 1971. Les Calpionelles Protozoaires planctoniques des mers mésogéennes de l'époque secondaire. Annales Guebhard Neuchatel, 47:370-393. 
Roncaglia, L. 2004. Palynofacies analysis and organic-walled dinoflagellate cysts as indicators of palaeo-hydrographic changes: an example from Holocene sediments in Skálafjord, Faroe Islands. Marine Micropaleontology, 50:21-42. doi:10.1016/ S0377-8398(03)00065-3

Roth, L. \& Lorscheitter, M.L. 2016. Fungi, algae, and other palynomorphs in sedimentary profiles collected from two forests in the northernmost coastal plain from Rio Grande do Sul, southern Brazil. Brazilian Journal of Botany, 34:1135-1143. doi:10.1007/s40415-016-0326-3

Rüst, D. 1885. Beiträge zur Kenntniss der fossilen Radiolerien aus Gesteinen de Jura. Palaeontographica, 11:273-321.

Sparica, M.; Koch, G.; Belak, M.; Miko, S.; Sparica-Miko, M.; Vilicic, D.; Dolenec, T.; Bergant, S.; Lojen, S.; Vreca, P.; Dolenec, M.; Ogrinc, N. \& Ibrahimpasic, H. 2005. Recent sediments of Makirina Cove (Northern Dalmatia, Croatia): their origin viewed through a multidisciplinary approach. Geologia Croatica, 58:21-72.

Stancliffe, R.P.W. 1989. Microforaminiferal linings: their classification, biostratigraphy and paleoecology, with special reference to specimens from British Oxfordian sediments. Micropaleontology, 35:337-352. doi:10.2307/1485676

Stancliffe, R.P.W. \& Matsuoka, K. 1991. Marine palynomorphs found in Holocene sediments of the coast of northwestern Kyushu, Japan. Bulletin Faculty of Liberal Arts, Nagasaki University (Natural Science), 31:661-681.

Stockmarr, J. 1971. Tablets with spores used in absolute pollen analysis. Pollen et Spores, 13:615-621.
Stuiver, M.; Reimer, P.J. \& Reimer, R.W. 2016. CALIB 7.1. Available at http://calib.org/calib/calib.html; accessed on 12/12/2017.

Tappan, H. \& Loeblich, A.R.J.R. 1968. Lorica composition of modern and fóssil tintinida (ciliate Protozoa), systematic, geologic distribution and some new tertiary taxa. Journal of Paleontology, 42:1378-1394.

Tenenbaum, D.R. \& Gomes, E.A.T. 2006. Dinoflagelados $e$ Tintinídeos da região central da Zona Econômica Exclusiva Brasileira: guia de identificação. Rio de Janeiro, Museu Nacional, 288 p.

Traverse, A. 1994. Sedimentation of palynomorphs and palynodebris: an introduction. In: A. Traverse (ed.) Sedimentation of organic particles, Cambridge University Press, p. 1-8.

Van Waveren, I.M. 1994. Tintinnomorphs from deep-sea sediments of the Banda Sea (Indonesia). Scripta Geologica, 105:27-51.

Van Waveren, I.M. \& Visscher, H. 1994. Analysis of the composition and selective preservation of organic matter in surficial deep-sea sediments from a high-productivity area (Banda Sea, Indonesia). Palaeogeography, Palaeoclimatology, Palaeoecology, 112:85111. doi:10.1016/0031-0182(94)90135-X

Wood, G.D.; Gabriel, A.M. \& Lawson, J.C. 1996. Palynologycal techniques-processing and microscopy. In: J. Jansonius \& D.C. Mcgregor (eds.) Palynology: principles and applications, American Association of Stratigraphic Palynologists Foundation, p. 29-50.

Received in March, 2017; accepted in December, 2017. 